\title{
OBSERVASI KEPUTUSAN BERKUNJUNG WISATAWAN PADA KAWASAN TAMAN WISATA ALAM GUNUNG TUNAK BERDASARKAN PENGARUH CITRA DESTINASI, PRODUK WISATA, DAN EWOM
}

\author{
Rionaldi Gigih Imam P1, Handry Sudiartha A $^{2}$, Lalu M. Furkan ${ }^{3}$ \\ ${ }^{1}$ Master of Management Program, Mataram University, Indonesia. \\ E-mail: rionaldigigih19@gmail.com \\ ${ }^{2}$ Faculty of Economics and Business, Mataram University, Indonesia. \\ E-mail: handrysudiartha@gmail.com \\ ${ }^{3}$ Faculty of Economics and Business, Mataram University, Indonesia.
}

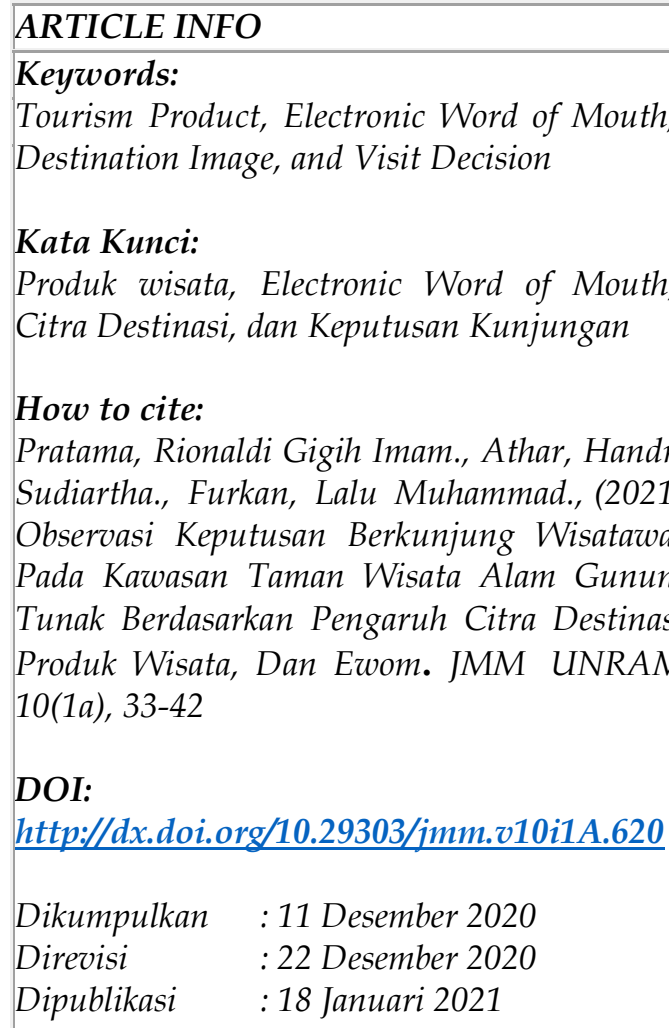

\section{ABSTRACT}

Taman Wisata Alam Gunung Tunak is located in Mertak Village, Pujut, Central Lombok, West Nusa Tenggara. Taman Wisata Alam Gunung Tunak has various potential tourist objects. This study aims to explain the influence of tourism products and electronic word of mouth on the decision to visit with destination images as a mediating variable in Gunung Tunak Nature Park. This research is a causal and associative research through a quantitative approach. The population in this study are visitors who visit the Taman Wisata Alam Gunung Tunak. The sample used in this study were 109 respondents with accidental sampling method. Based on the results of the analysis of the influence of tourism products and e-WOM on visiting decisions, it is concluded that the variables of tourism products and e-WOM have a significant positive effect on the variable of tourist decisions to visit in Taman Wisata Alam Gunung Tunak. Then the tourism product variables and e-WOM have a positive effect on the image of the destination, and the variable of destination image has a positive effect on the decision to visit. In addition, the variable of destination ctra also partially mediates the effect of wsata and e-WOM products on the decision to visit tourists.

Taman Wisata Alam Gunung Tunak berlokasi di Desa Mertak, Pujut, Lombok Tengah, Nusa Tenggara Barat. Taman wisata alam gunung tunak memiliki potensi objek wisata yang beragam. Penelitian ini bertujuan untuk menjelaskan pengaruh produk wisata dan electronic word of mouth terhadap keputusan berkunjung dengan citra destinasi sebagai variabel mediasi di Taman Wisata Alam Gunung Tunak. Penelitian ini merupakan penelitian yang bersifat kausal dan asosiatif melalui pendekatan kuantitatif.Populasi dalam penelitian ini adalah 


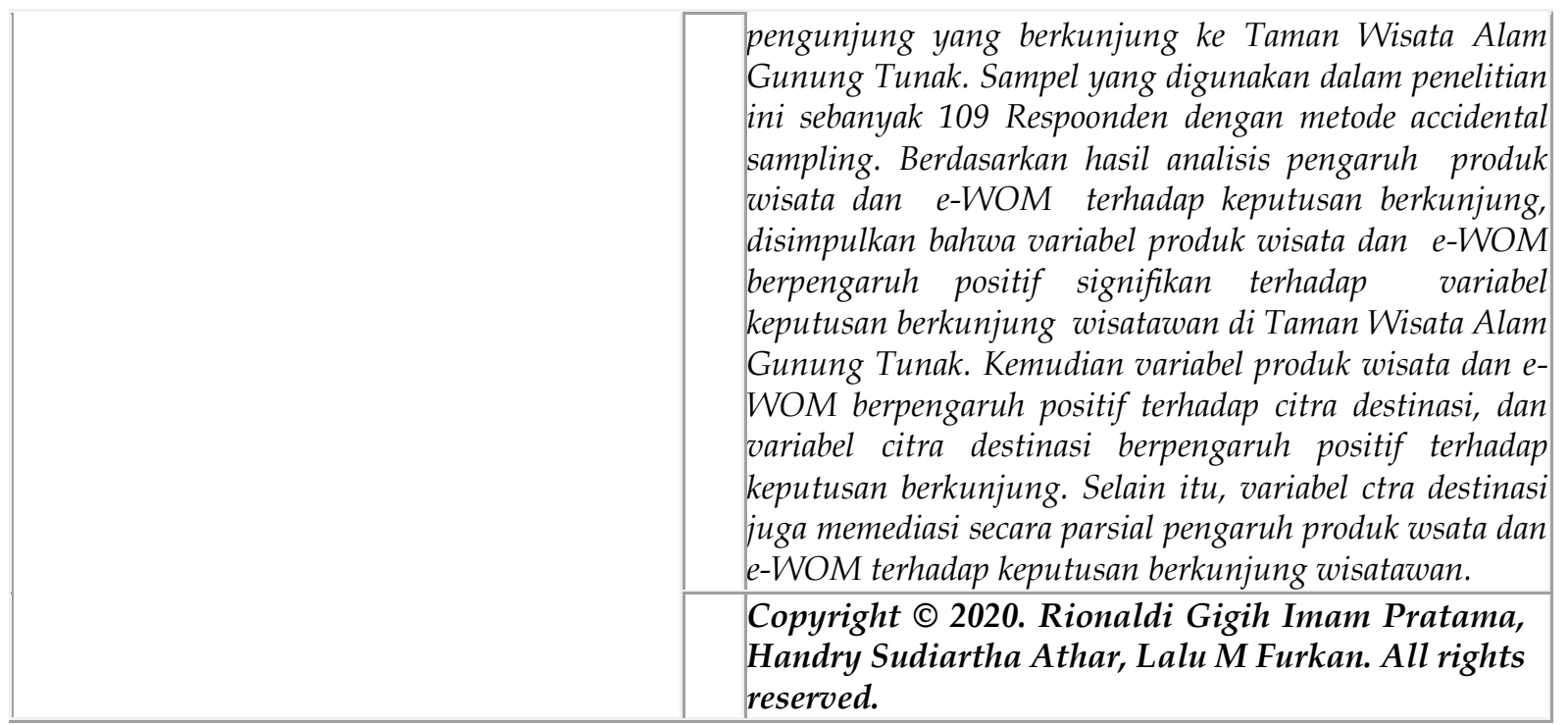

\section{PENDAHULUAN}

Taman Wisata Alam Gunung Tunak memiliki sebuah resort yang bernama Tunak Cottage \& Restaurant. Tunak Cottage \& Restaurant yang merupakan resort dari kawasan Taman Wisata Alam Gunung Tunak sebagai tempat penginapan wisatawan yang berkunjung serta pos jaga depan tempat konservasi. Upaya penetapan kawasan konservasi ini merupakan langkah awal untuk melindungi kekayaan keanekaragaman hayati yang ada di dalamnya. Taman Wisata Alam Gunung Tunak terdapat berbagai macam spot wisata seperti, camping ground, Pusat Ekologi kupu-kupu, penangkaran rusa Timor, serta pantai yang dikelilingi bukit kapur dan hamparan pasir putih. Taman Wisata Alam Gunung Tunak Memiliki Pengunjung Yang terus Meningkat tiap tahunnya. Selain itu juga, setiap tahunnya juga tempat ini memiliki tradisi Petaek Kao atau menaikkan Kerbau yang digelar pada saat bulan Sepuluh penanggalan sasak yaitu antara Februari dan Maret. Tradisi ini dapat membuat wisatawan tertarik untuk mencobanya dan biasanya juga wisatawan ikut memandikan kerbau yang sudah berendam di lumpur (Ersya Mayana, Elina Rizki Cahyani, 2019).

Kesediaan konsumen untuk menceritakan dan memposting hal positif dari sebuah tempat wisata, atribut produk wisata yang ada dan juga citra dari destinasi wisata itu sendiri bisa mempengaruhi keputusanpara calon pengunjung untuk mengunjungi suatu objek wisata. Hal ini sesuai dengan hasil penelitian Nurul Retno Hapsari, dkk (2014) yang menyatakan bahwa, "atribut produk wisata dan electronic word of mouth berpengaruh terhadap keputusan berkunjung". Begitu juga dengan penelitian Priyanto, dkk (2016) yang menyatakan, "destination image atau citra destinasi berpengaruh dan signifikan terhadap keputusan berkunjung."

Tingkat kunjungan wisata ke Taman Wisata Alam Gunung Tunak dapat dikatakan cukup tinggi. Data kunjungan wisata ke Taman Wisata Alam Gunung Tunak yang bersumber dari Balai Konservasi Sumber Daya Alam Nusa Tenggara Barat (KSDA NTB) pada tahun 2014 sejumlah 554 wisatawan. Pada tahun 2015 jumlah kunjungan meningkat sebanyak 4698 wisatawan. Jumlah kunjungan wisata pada tahun 2014-2015 mengalami kenaikan, sedangkan pada tahun 2015-2016 terjadi penurunan jumlah wisatawan hingga $30 \%$. Tidak terlepas dari berbagai pengaruh maupun perubahan yang terjadi pada TWA Gunung Tunak tentu menjadi pembahasan yang menarik untuk meneliti bagaimana 
sebenarmya pengaruh produk wisata, E-Wom, citra destinasi, terhadap keputusan berkunjung dari wisatawan pada destinasi TWA Gunung Tunak

Berdasarkan fenomena yang dikemukakan diatas, maka TWA Gunung Tunak dinilai sangat menarik untuk diteliti. Sehingga penulis tertarik untuk mengangkat tema ini sebagai objek penelitian.

\section{KAJIAN LITERATUR}

\subsection{Keputusan Berkunjung}

Menurut Kotler dan Armstrong (2008:18) "keputusan pembelian adalah membeli merek yang paling disukai dari berbagai alternatif yang ada". Pranoto (2008), juga menjelaskan "perilaku pengambilan keputusan oleh konsumen untuk melakukan pembelian produk atau jasa diawali dengan adanya kesadaran atas pemenuhan kebutuhan atau keinginan dan menyadari adanya masalah selanjutnya, maka konsumen akan melakukan beberapa tahap yang pada akhirnya sampai pada tahap evaluasi pasca pembelian". Swastha dan Irawan, (2005: 118), "Setiap keputusan pembelian memilki struktur tujuh komponen yaitu struktur tentang merek, penjualnya, cara pembayaran, jumlah produk, bentuk produk, jenis produk serta waktu pembeliannya". Jalilvand dkk, (2012:12), "Yang menyamakan bahwa keputusan berkunjung wisatawan sama dengan keputusan pembelian konsumen. Keputusan berkunjung merupakan proses dimana seorang pengunjung melakukan penilaian dan memilih satu alternatif yang diperlukan berdasarkan pertimbangan tertentu".

\subsection{Citra Destinasi}

Citra destinasi menjadi salah satu faktor yang dapat mempengaruhi pilihan wisatawan, Moreira\& Iao, (2014). Citra destinasi memainkan peran dalam evaluasi atau perilaku wisatawan yang terkait dengan pemilihan tujuan wisata, minat berkunjung wisatawan di masa yang akan datang dan kesediaan wisatawan dalam memberi rekomendasi, Moreira\& Iao (2014). Citra destinasi mampu menggerakkan dan mendorong wisatawan menentukan pilihan destinasi wisatanya. Destinasi wisata yang memberikan pengalaman menyenangkan bagi wisatawan memiliki pengaruh besar pada pengembangan citra positif, M. R. Jalilvand, Ebrahimi, \& Samiei, (2013). Semakin positif citra destinasi tersebut, semakin tinggi probabilitas destinasi dipertimbangkan dan dipilih, Moreira \& Iao, (2014).

\subsection{Produk Wisata}

"Produk adalah sesuatu yang dapat ditawarkan ke pasar untuk mendapatkan perhatian, akuisisi, penggunaan, atau konsumsi yang dapat memuaskan keinginan atau kebutuhan. Ini mencakup objek fisik, layanan, tempat, organisasi, dan gagasan" (Kotler, 2009:304). "Produk pada industri pariwisata merupakan product line, yaitu produk yang penggunaannya dilakukan pada waktu bersamaan" (Yoeti, 2008:70). Sedangkan menurut Cooper terdapat 4 (empat) komponen yang harus dimiliki oleh sebuah daya tarik wisata yaitu:

(1) Pertama, atraksi (attractions), seperti alam yang menarik, kebudayaan daerah yang menawan dan seni pertunjukkan;

(2) Kedua, aksesibilitas (accessibilities), seperti transportasi lokal dan adanya terminal;

(3) Ketiga, amenitas atau fasilitas (amenities), seperti tersedianya akomodasi, rumah makan, dan agen perjalanan; 
(4) Keempat, ancillary services yaitu organisasi kepariwisataan yang dibutuhkan untuk pelayanan wisatawan seperti organisasi manajemen pemasaran wisata (Cooper, 2005)

\subsection{Elektronik Word Of Mouth (EWOM)}

"Electronic Word of mouth merupakan bentuk pujian, rekomendasi, dan komentar pelanggan sekitar pengalaman mereka atas layanan jasa dan produk yang betul -betul memengaruhi keputusan pelanggan atau perilaku pembelian mereka".

Menurut Thurau et al., (2004) EWOM merupakan bentuk komunikasi pemasaran yang berisi tentang pernyataan positif atau negatif yang dilakukan konsumen potensial, maupun mantan konsumen tentang suatu produk, yang tersedia bagi orang banyak melalui media sosial internet. Konsumen cenderung menerima saran-saran dari kerabat, teman, dan kolega karena tingginya kredibilitas di antara mereka ketika membicarakan mengenai produk yang dikonsumsi.Word of Mouth Association (WOMMA) mendefinisikan secara sederhana mengenai Word Of Mouth marketing sebagai tindakan seseorang dalam berbagi suatu informasi yang menarik kepada orang lain (womma.org: 2013). EWOM merupakan komunikasi pemasaran yang dilakukan secara online melalui media sosial internet (Schiffman dan Kanuk dalam Haekal, 2016: 27). Dari penjelasan di atas dapat ditarik kesimpulan bahwa EWOM merupakan komunikasi pemasaran yang berbasis online melalui media sosial internet yang memiliki pesan berisi tentang pernyataan positif atau negatif yang dilakukan oleh konsumen potensial atau mantan konsumen. Dengan adanya EWOM komunikasi antara produsen dan konsumen menjadi lebih mudah, dan sesuai dengan kemajuan zaman saat ini.

\subsection{Hubungan Antara Variabel}

Pengaruh Produk Wisata terhadap keputusan berkunjung dengan citra destinasi sebagai variabel mediasi

Sebagai sebuah produk wisata, kawasan wisata alam juga memerlukan suatu pengembangan. Faktor yang menjadi dasar pengambilan keputusan berkunjung adalah produk wisata maka dari itu salah satu fungsi produk wisata yaitu sebagai referensi wisatawan dalam setiap melakukan kunjungan ke suatu objek wisata (Huda, Rachma, \& Hufron, 2019).

Calon pengunjung akan lebih merasa tertarik mengunjungi destinasi dengan citra yang positif, sedangkan pengunjung yang telah berhasil merasa puas dengan citra positif tersebut memungkinkanuntuk melakukan kunjungan ulang dan merekomendasikan destinasi ke calon pengunjung lain.Citra (image) pariwisata menurut Pitana dan Diarta (2009) adalah kepercayaan yang dimiliki oleh wisatawan mengenai produk atau pelayanan yang wisatawan beli atau akan beli. Citra destinasi tidak selalu terbentuk dari pengalaman atau fakta, tetapi dapat dibentuk sehingga menjadi faktor motivasi atau pendorong yang kuat untuk melakukan perjalanan wisatawan ke suatu destinasi pariwisata.

H1: Citra Destinasi memperkuat pengaruh produk wisata terhadap keputusan berkunjung

Pengaruh Electronic word of mouth terhadap keputusan berkunjung dengan citra destinasi sebagai variable mediasi

Hennig -Thurau et. al., (2004), mengemukakan bahwa electronic word of mouth adalah pernyataan positif ataupun negatif yang dilakukan oleh pelanggan potensial ataupun mantan pelanggan tentang produk atau perusahaan, yang ditujukan untuk banyak orang atau lembaga via internet.Komunikasi electronic word of mouth yang terbentuk di sosial media memungkinkan penggunanya untuk saling berbagi informasi. Media sosial berkontribusi dalam penyampaian pesan-pesan pembangunan, termasuk di sektor 
pariwisata yang digunakan sebagai media promosi. Survei menyatakan sebanyak $87 \%$ pelancong menggunakan internet untuk merencanakan perjalanan wisata mereka dan sebanyak $40 \%$ dari wisatawan mengunjungi situs jejaring sosial untuk memilih tujuan liburan berdasarkan rekomendasi dari para pengguna media sosial (Toffeenet.com, 2015 dalam Nevit, 2016).

Komunikasi electronic word of mouth ini sangat berpengaruh terhadap konsumen yang tertarik dengan saran dari orang yang telah memiliki pengalaman terhadap destinasi wisata sehingga akan memunculkan citra merek suatu destinasi dan mempengaruhi keputusan untuk berkunjung karena rasa penasaran atas ulasan yang dilihatnya melalui media sosial. Dengan kata lain, kesan wisatawan terhadap destinasi wisata dapat timbul setelah melihat posting maupun membaca komentar yang ada pada akun media sosial tentang destinasi wisata. Hal ini sejalan dengan pendapat yang diungkapkan Kotler (2000) bahwa setiap pelanggan memiliki kesan tertentu terhadap suatu merek, yang timbul setelah melihat, mendengar, membaca atau merasakan merek produk, baik melalui TV, radio, maupun media cetak. Kemudian semakin baik electronic word of mouth maka semakin meningkat pula wisatawan yang memutuskan untuk melakukan kunjungan pada suatu destinasi wisata sehingga dengan adanya komunikasi electronic word of mouth yang terjadi di media sosial menjadi dorongan atau rangsangan internal yang kuat dalam memotivasi followers akun media social untuk melakukan tindakan, dimana dorongan ini dipengaruhi oleh stimulus berupa sharing informasi antar pengguna maupun posting destinasi wisata dari akun tersebut.

H2: Citra Destinasi memperkuat pengaruh Electronic Word Of Mouth terhadap keputusan berkunjung

\section{METODE PENELITIAN}

Penelitian ini merupakan penelitian yang bersifat kausal dan asosiatif melalui pendekatan kuantitatif. Penelitian ini menggunakan metode deskriptif dan asosiatif melalui pendekatan kuantitatif. Populasi dalam penelitian ini adalah objek wisata dan wisatawan yang berkunjung ke Obyek Wisata TWA Gunung Tunak. Teknik penentuan sampel yang digunakan adalah Accidental Sampling (Pada metode penentuan sampel tanpa sengaja (accidental) ini, peneliti mengambil sampel yang kebetulan ditemuinya pada saat itu.Teknik analisis data pada penelitian ini adalah analisis jalur (path analysis). Rumus Slovin digunakan untuk menentukan banyaknya sampel dalam survei yang bertujuan untuk mengestimasi proporsi yang menghasilkan nilai varian tertinggi.Ukuran sampel dihitung dengan menggunaan rumus Slovin.

Keterangan :

$$
n=\frac{N}{1+N \alpha^{2}}
$$

$$
\begin{aligned}
& \mathrm{N}=\text { Banyaknya Populasi } \\
& \mathrm{n}=\text { Banyaknya Sampel } \\
& \mathrm{a}=\text { Error kesalahan }
\end{aligned}
$$

Data yang didapat jumlah pengunjung rata-rata dalam kurun waktu 1 bulan mencapai 150 pengnjung.Data tersebut di ambil sebagai banyaknya populasi.Berdasarkan rumus tersebut, dengan derajat kesalahan sebesar 5\%,

$$
\begin{array}{ll} 
& \mathrm{n}=\mathrm{N} /\left(1+\left(\mathrm{N} \times \mathrm{e}^{2}\right)\right) \\
\text { Sehingga: } & \mathrm{n}=150 /\left(1+\left(150 \times 0,05^{2}\right)\right) \\
& \mathrm{n}=150 /(1+(150 \times 0,0025)) \\
& \mathrm{n}=150 /(1+0,375)
\end{array}
$$




$$
\begin{aligned}
& \mathrm{n}=150 / 1,375 \\
& \mathrm{n}=109,0909 \approx 109
\end{aligned}
$$

maka jumlah responden yang dijadikan ukuran sampel dalam penelitian ini ialah sebanyak 109 wisatawan. Sampel pada penelitian ini adalah wisatawan yang berkunjung ke TWA Gunung Tunak

\section{HASIL PENELITIAN DAN PEMBAHASAN}

\subsection{Hasil Path Analysis}

Pengaruh Produk Wisata (X1) dan Word of Mouth (X2) Terhadap Keputusan Berkunjung (Y) melalui Citra Destinasi (Y1) sebagai variabel Mediasi

Analisis path adalah metode untuk mengetahui pengaruh secara langsung maupun tidak langsung dari variabel bebas terhadap variabel terikat. Analisis dilakukan dengan software AMOS.

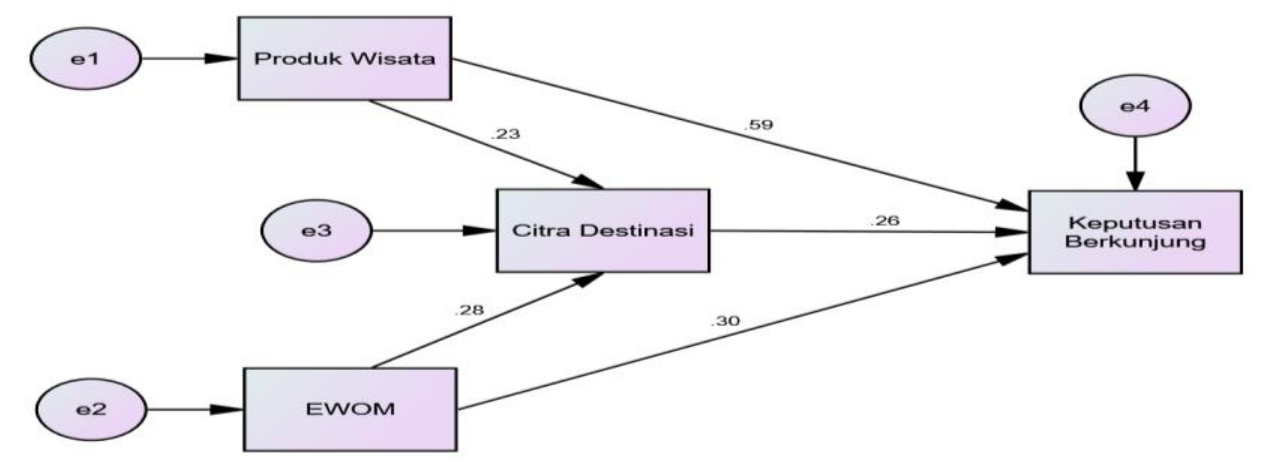

Gambar 4.1 Diagram Path

Tabel 4.1. Hasil Path Analysis

\begin{tabular}{|c|c|c|c|}
\hline \multirow{2}{*}{ No. } & Pengaruh Variabel & \multicolumn{2}{|c|}{ Pengaruh Kausal } \\
\cline { 3 - 4 } & & Langsung & Tidak Langsung \\
\hline 1 & X1 terhadap Y1 & 0,230 & \\
\hline 2 & X2 terhadap Y1 & 0,284 & \\
\hline 3 & Y1 terhadap Y & 0,262 & \\
\hline 4 & X1 terhadap Y & 0,591 & \\
\hline 5 & X2 terhadap Y & 0,296 & \\
\hline 6 & X1 terhadap Y melalui Y1 & & 0,060 \\
\hline 7 & X2 terhadap Y melalui Y1 & & 0,074 \\
\hline
\end{tabular}

Sumber: Data Primer Diolah 2020

Tabel 4.2 Hasil Uji Setelah Citra Destinasi dimasukkan sebagai variabel mediasi

\begin{tabular}{|c|c|c|c|}
\hline No. & Pengaruh Variabel & Langsung & Melalui Y1 \\
\hline 1 & X1 terhadap Y & 0,591 & 0,422 \\
\hline 2 & X2 terhadap Y & 0,296 & 0,276 \\
\hline
\end{tabular}

Sumber: Data Primer Diolah 2020 
Berdasarkan hasil di atas diperoleh anlisis pengaruh sebagai berikut:

1. Pengaruh Citra Destinasi (Y1) terhadap Keputusan Berkunjung (Y)

Pengaruh yang diberikan Y1 terhadap Y sebesar 0,262.

2. Pengaruh Produk Wisata (X1) terhadap Keputusan Berkunjung (Y)

Pengaruh langsung yang diberikan $X 1$ terhadap $Y$ sebesar 0,591 , sedangkan pengaruh tidak langsung X1 melalui $Y 1$ terhadap $Y$ adalah $0,23 \times 0,262=0,060$. Maka pengaruh total $\mathrm{X} 1$ terhadap $\mathrm{Y} 1$ adalah pengaruh langsung ditambah dengan pengaruh tidak langsung yaitu : 0,591 $+0,060=0,651$. Berdasarkan hasil perhitungan diketahui bahwa nilai pengaruh langsung sebesar 0,591 dan pengaruh tidak langsung sebesar 0,060 yang berarti bahwa nilai pengaruh tidak langsung lebih kecil dibandingkan dengan nilai pengaruh langsung, hasil ini menunjukkan bahwa secara tidak langsung X1 melalui Y1 mempunyai pengaruh tidak signifikan terhadap Y. Selain itu, dapat dilihat jika pengaruh variabel Produk Wisata terhadap Proses Keputusan Berkunjung tetap signifikan tetapi nilainya menurun ketika variabel Citra Destinasi dimasukkan, dari yang nilainya 0,591 menjadi 0,422, sehingga terbukti jika Citra Destinasi menjadi mediator hubungan Produk terhadap Proses Keputusan Berkunjung. Nilai pengaruh langsung Produk Wisata terhadap Proses Keputusan Berkunjung setelah memasukkan Citra Destinasi tidak sama dengan nol, maka variabel Citra Destinasi adalah sebagai mediasi parsial.

3. Pengaruh EWOM (X2) terhadap Keputusan Berkunjung (Y)

Berdasarkan hasil analisis pengaruh e-WOM terhadap keputusan berkunjung, disimpulkan bahwa variabel e-WOM berpengaruh positif signifikan terhadap variabel keputusan berkunjung wisatawan di Taman Wisata Alam Gunung Tunak. Hasil tersebut memberikan makna bahwasanya semakinjelas informasi yang disebar, sehingga mampu memberikan wawasan dan pengetahuan kepada para pengunjung dalam mencari informasi wisata Taman Wisata Alam Gunung Tunak, maka tingkat kunjungan wisatawan akan semakin tinggi.

Pengaruh langsung yang diberikan $X 2$ terhadap $Y$ sebesar 0,291 atau 0,3 . Pengaruh tidak langsung X2 melalui Y1 terhadap $Y$ adalah 0,284 x 0,262 = 0,074. Maka pengaruh total $\mathrm{X} 1$ terhadap $\mathrm{Y} 1$ adalah pengaruh langsung ditambah dengan pengaruh tidak langsung yaitu : 0,291 $+0,074=0,365$. Berdasarkan hasil perhitungan diketahui bahwa nilai pengaruh langsung sebesar 0,291 dan pengaruh tidak langsung sebesar 0,074 yang berarti bahwa nilai pengaruh tidak langsung lebih kecil dibandingkan dengan nilai pengaruh langsung, hasil ini menunjukkan bahwa secara tidak langsung X2 melalui Y1 mempunyai pengaruh tidak signifikan terhadap Y. Selain itu, dapat dilihat jika pengaruh variabel Produk Wisata terhadap Proses Keputusan Berkunjung tetap signifikan tetapi nilainya menurun ketika variabel Citra Destinasi dimasukkan, dari yang nilainya 0,296 menjadi 0,276, sehingga terbukti jika Citra Destinasi menjadi mediator hubungan Produk terhadap Proses Keputusan Berkunjung. Nilai pengaruh langsung Produk Wisata terhadap Proses Keputusan Berkunjung setelah memasukkan Citra Destinasi tidak sama dengan nol, maka variabel Citra Destinasi adalah sebagai mediasi parsial. 


\subsection{Uji Hipotesis}

\section{Uji t}

Pengaruh Produk Wisata (X1) dan Electronic Word of Mouth (X2) terhadap Keputusan Berkunjung (Y) melalui Citra Destinasi (Y1) sebagai variabel Mediasi

Coefficients ${ }^{\mathrm{a}}$

\begin{tabular}{|c|c|c|}
\hline Model & $\mathrm{T}$ & Sig. \\
\hline 1 (Constant) & -2.115 & .037 \\
Produk Wisata & 9.315 & .000 \\
Word of Mouth & 4.597 & .000 \\
Citra Destinasi & 4.055 & .000 \\
\hline
\end{tabular}

Nilai uji-t variabel Citra Destinasi (Y1) sejumlah 0,000 yang berarti kurang dari 0,05 yang berarti Citra Destinasi (Y1) berpengaruh terhadap variabel Keputusan Berkunjung (Y).Pengaruh Produk wisata (X1) terhadap Keputusan Berkunjung (Y) melalui Citra Destinasi (Y1) Hasil pengujian hipotesis menunjukkan bahwa Produk wisata (X1) mempunyai pengaruh positif terhadap keputusan berkunjung melalui citra destinasi dengan nilai uji T-statistic > 1,96 yaitu sebesar 9,315 serta sig 0,000<0,05 sehingga dapat disimpulkan produk wisata (X1) berpengaruh positif terhadap keputusan berkunjung (Y) melalui citra destinasi (Y1). Pengaruh Electronic Word of Mouth (X2) terhadap Keputusan Berkunjung (Y) melalui Citra Destinasi (Y1) Hasil pengujian hipotesis menunjukkan bahwa Electronic Word Of Mouth (X2) mempunyai pengaruh positif terhadap keputusan berkunjung $(\mathrm{Y})$ melalui citra destinasi $(\mathrm{Y} 1)$ dengan nilai uji T-statistic $>$ 1,96 yaitu sebesar 4,597 serta sig 0,000 < 0,05 sehingga dapat disimpulkan electronic word of mouth $(\mathrm{X} 2)$ berpengaruh positif terhadap keputusan berkunjung $(\mathrm{Y})$ melalui citra destinasi (Y1).

\section{KESIMPULAN DAN SARAN}

\subsection{Kesimpulan}

Dari hasil penelitian ini dapat di Tarik beberapa kesimpulan sebagai berikut :

1. Dari hasil penelitian ini Secara tidak langsung produk wisata melalui Citra Destinasi tidak berpengaruh singnifikan terhadap keputusan berkunjung. Produk Wisata dapat meningkatkan Keputusan Berkunjung melalui Citra Destinasi. Dengan menyediakan Produk Wisata yang menarik dapat meningkatkan Citra Destinasi dimatapengunjung. Hal ini mempengaruhi konsumen untuk melakukan KeputusanBerkunjung.

2. Secara tidak langsung Electronic Word Of Mouth melalui Citra Destinasi tidak berpengaruh singnifikan terhadap keputusan berkunjung. Electronic Word of Mouth dapat meningkatkan Keputusan Berkunjung melalui Citra Destinasi. Semakin banyak yang menyebarkan atau menceritakan topik mengenai suatu destinasi wisata hal ini meningkatkan citra atau nama baik tempat wisata sehingga mampu mempengaruhi konsumen untuk melakukan KeputusanBerkunjung.

\subsection{Saran}

Penelitian ini menawarkan beberapa implikasi praktis. Pertama, Disarankan kepada pihak pengelola TWA Gunung Tunak untuk lebih memperbanyak promosi dan informasiinformasi mengenai TWA Gunung Tunak melalui media sosial instagram, hal ini dikarenakan saat ini masyarakat lebih sering mencari informasi mengenai objek wisata yang 
akan dikunjungi melalui media sosial salah satunya adalah instagram. Pihak pengelola juga diharapkan untuk terus menjaga dan meningkatkan fasilitas-fasilitas yang ada dan pengelola juga bisa menambahkan tempat-tempat yang lebih instagramable yang bisa menarik minat wisatawan berkunjung. Pihak pengelola bisa memberikan inovasi untuk produk-produk yang bisa dijadikan ciri khas dari TWA Gunung Tunak ini sendiri dan pengelola bisa bekerja sama dengan masyarakat sekitar untuk mengisi lapak tempat berdagang yang masih ada beberapa belum dimanfaatkan, hal ini tentunya bisa menambah penghasilan masyarakat sekitar. Diharapkan untuk kedepannya pengelola TWA Gunung Tunak mempertimbangkan saran dalam penelitan ini supaya wisata TWA Gunung Tunak lebih memiliki daya tarik yang besar untuk dikunjungi wisatawan baik wisatawan domestic maupu wisatawan mancanegara.

Dalam penelitian ini hanya terbatas dalam meniliti pengaruh dari variabel Citra Destinasi, Produk Wisata dan Electronic Word Of Mouth terhadap keputusan berjunjung, Sehingga variabel-variabel lain yang berpengaruh terhadap keputusan berkunjung tidak dibahas dalam penelitian ini. Dan keterbatasan waktu maka penelitian ini meneliti 3 variabel. Dengan begitu kepada peneliti selanjutnya hendaknya untuk menambah variabel -variabel lain yang lebih berpengaruh dengan variabel Keputusan Berkunjung.Bagi penelitian selanjutnya disarankan dapat meneliti kemungkinan variabel lain yang dapat mempengaruhi keputusan berkunjung yaitu variabel bauran promosi, harga dan lokasi.

Peneliti berharap dalam penelitian selanjutnya mampu mencakup ruang lingkup yang lebih luas, tidak terbatas oleh satu destinasi wisata. Serta disarankan untuk penelitian selanjutnya mencoba melakukan penelitian pada destinasi wisata dengan jenis wisata yang berbeda, seperti obyek wisata wahana permainan atau destinasi wisata alam baik itu pantai maupun pegunungan, hal ini untuk melihat bagaimana hasil yang diperoleh jika variabelvariabel dalam penelitian ini terhadap jenis destinasi wisata lainnya.

\section{DAFTAR PUSTAKA}

Cooper, dkk. 2005. Tourism Principle and Practive Third Edition. Harlow: Prentice Hall.

Haekal, M. E., Suharyono, \& Yuliyanto, E. (2016). Pengaruh EWOM terhadap Kepercayaan dan Keputusan Pembelian (Survei pada konsumen produk fashion Followers akun Instagram Erigostore). Jurnal ADBIS (JAB), Vol 40 No. 2.

Hapsari, Nurul Retno, Nawazirul Lubis, dan Widiartanto. 2014. Pengaruh Atribut Produk Wisata dan Electronic Word of Mouth (e-WOM) terhadap Keputusan Berkunjung pada Objek Wisata Umbul Sidomukti Kabupaten Semarang. Jurnal Ilmu Administrasi Bisnis.

Hasan, Ali. 2010. Merketing dari Mulut ke Mulut (word of Mouth Marketing).Yogyakarta, MEDPRESS

Huda, kamal musthofa, Rachma, N., \& Hufron, M. (2019). Pengaruh Citra Destinasi,Produk Wisata dan Word of Mouth Terhadap Keputusan Berkunjung ke TWA Gunung Tunak. E- Jurnal Riset Manajemen, 8(1), 90-101.

Jalilvand, M. R and Samiei, N. 2012. The Effect of Electronic Word Of Mouth on Brand Image and Purchase Intention: An Empirical Study in TheAutomobile Industry in Iran". Marketing Intelligence\& Planning, Vol. 30 No. 4, pp. 460-476.

Jalilvand, M. R., Ebrahimi, A., \& Samiei, N. (2013). Electronic Word of Mouth Effects on Tourists' Attitudes Toward Islamic Destinations and Travel Intention: An Empirical Study in Iran. Procedia - Social and Behavioral Sciences, 81(2006), 484-489. https://doi.org/10.1016/j.sbspro.2013.06.465 
Kotler, Philip. 2000. Manajemen Pemasaran di Indonesia Analisis Perencanaan, Implementasi, dan Pengendalian. Dialihbahasakan oleh A.B Susanto. Jakarta: Salemba Empat.

Kotler, Philip, and Amstrong Gery. (2008). Dasar-dasar Pemasaran Edisi 12nd Jilid 2. Jakarta. Erlangga.

Kotler, Philip, dan Keven L Keller. 2009. Manajemen Pemasaran Jilid ke 1 Edisi 12.Alih bahasa Bob Sabran. Jakarta: Indeksia.

Mayana, Ersya, Elina Rizki Cahyani, 2019. Potensi Obyek Wisata Taman Wisata Alam Gunung Tunak. https://doi.org/10.29303/jseh.v5i2.40

Moreira, P., \& Iao, C. (2014). A Longitudinal Study on the Factors of Destination Image, Destination Attraction and Destination Loyalty. International Journal of Social Sciences, 3(3), 90-112.

Mubarokah, Fatah. (2019). Pengaruh Electronic Word Of Mouth Dan Produk Wisata Terhadap Keputusan Berkunjung Dengan Citra Destinasi Sebagai Variabel Mediasi Pada Saung Angklung Udjo (Studi Pada Followers Akun Instagram Saung Angklung Udjo). Jurnal Administrasi Bisnis.Universitas Muhammadiyah, Yogyakarta.Retrievedfromhttp:// search.proquest.com/docview/1647350826?acco untid $=14542$

Pitana, I Gde.dan Surya Diarta, I Ketut. (2009). Pengantar Ilmu Pariwisata. Yogyakarta: Penerbit Andi

Pranoto (2008), juga menjelaskan "perilaku pengambilan keputusan oleh konsumen untuk melakukan pembelian produk atau jasa

Priyanto , Widiartanto \& Listyorini (2016). Pengarih Produk Wisata, DestinationImage dan Word of Mouth Terhadap Keputusan Berkunjung (Studi KasusPada Pengunjung Objek Wisata Goa Kreo Semarang)

Schiffman L., dan Kanuk L.L., (2012), Perilaku Konsumen, Penerbit: Indeks, Jakarta.

Swastha,Basu dan Irawan. 2005. Manajemen Pemasaran Modern. Ed.2. Yogyakarta: Liberty.

Thurau, et al,. 2004. Electronic Word of Mouth: Motives for and Consequences of Reading customerArticulations on the Internet. Journal of Interactive Marketing.Vol. 18. No. (1)

Toffeenet.com, 2015 dalamNevit,2016http://isparmo.web.id/2016/11/21/datastatistikpengguna-internetindonesia2016/,diakses Mei 2017

Womma.org website. Word Of Mouth Marketing Association, Diakses November 2007. Dikutip dalam Saptaningsih Sumarni, "Fenomena Word of Mouth Marketing dalam Mempengaruhi Keputusan Konsumen". 2008

Yoeti, O. (2008). Perencanaan Dan Pengembangan Pariwisata. Jakarta: Erlangga

Zakia, S, Farida, N \& Widiartanto.2016. Pengaruh Produk Wisata, dan Word of Mouth Terhadap Keputusan Berkunjung Dengan Citra Destinasi Sebagai Variabel Intervening (Studi Pada Obyek Wisata Colo Kudus)', JurnalAdministrasi Bisnis. Universitas Diponegoro, Semarang. 